\title{
CANYON GRASSLAND VEGETATION CHANGES FOLLOWING FIRE IN NORTHERN IDAHO
}

\author{
Corey L. Gucker ${ }^{1,2}$ and Stephen C. Bunting ${ }^{1}$
}

\begin{abstract}
Native and nonnative vegetation mosaics are common in western rangelands. If land managers could better predict changes in the abundance of native and nonnative species following disturbances, maintenance of native plant cover and diversity may be improved. In August 2000, during suppression of a wildfire near Lewiston, Idaho, a backing fire burned canyon grassland plots. A previous study had recorded species composition and cover prior to the fire, so we were able to evaluate changes in species composition and abundance on established plots before and after the fire. Overall, summer burning had little effect on the grassland communities. Pseudoroegneria spicata recovered to prefire coverage by the third postfire year. In the third postfire year, cover of native and nonnative annual species was significantly greater on burned than unburned sites $(P<0.03)$. Bromus tectorum cover increased, as expected, on burned plots. Prefire and postfire cover values for Centaurea solstitialis were nearly equal, and there were no significant cover differences between burned and unburned plots in any year. As part of this study, we also evaluated changes in the cover of dominant native and nonnative species with respect to their prefire seral stage on burned and unburned plots. Because our sample sizes were small, we only report community-level trends but suggest that this type of community analysis could make for an interesting future study.
\end{abstract}

RESUMEN.-Los mosaicos de vegetación nativa y no nativa son comunes en los pastizales del occidente de Norteamérica. Si los administradores de tierras pudieran predecir mejor los cambios en la abundancia de especies nativas y no nativas después de las perturbaciones, se podría mejorar el mantenimiento de la cobertura y diversidad de las plantas nativas. En agosto de 2000, los remanentes de un incendio quemaron terrenos de pradera de cañón durante la supresión de un incendio cerca de Lewiston, Idaho. Un estudio previo registró la composición y cobertura de especies antes del incendio, por lo que pudimos evaluar los cambios en la composición y abundancia de especies en determinados terrenos antes y después del incendio. En general, las quemas de verano no afectaron mucho a las comunidades de pradera. Para el tercer año después del incendio, Pseudoroegneria spicata se había repuesto al nivel de cobertura que tuvo antes del incendio y la cobertura de especies anuales nativas y no nativas fue significativamente mayor $(P<0.03)$ en los sitios quemados que en los no quemados. Tal como se esperaba, la cobertura de Bromus tectorum aumentó en los terrenos quemados. Los niveles de cobertura de Centaurea solstitialis antes y después del incendio fueron casi iguales, y no hubo ninguna diferencia significativa en la cobertura de los terrenos quemados y la de los no quemados en ninguno de estos años. Como parte de este estudio, también evaluamos los cambios en la cobertura de especies dominantes nativas y no nativas con respecto a su estado sucesional previo al incendio en terrenos quemados y no quemados. Debido a que tuvimos un reducido tamaño de muestra, sólo reportamos tendencias a nivel de comunidad, pero sugerimos que esta clase de análisis de comunidades podrían servir como modelo para estudios interesantes en el futuro.

Conservationists and ecologists generally agree that restoring historic disturbance patterns is important for landscape restoration (Hobbs and Huenneke 1992, Arno 1996, Greene and Evenden 1996) because ecosystems are adapted to and even require particular disturbance regimes to maintain species composition, community structure, and ecosystem function (Christensen et al. 1996, Leach and Givnish 1996). Reintroduced or natural disturbances in compositionally and/or functionally altered ecosystems, however, are challenging to manage. Understanding how disturbances affect altered communities is necessary to maintain native communities and prevent the spread of nonnative species.
In the canyon grasslands of Idaho, fire was common before the introduction of heavy livestock grazing (Tisdale 1979) and active fire suppression (Johnson 1989). Dry, hot summers create fuel conditions that can easily support fire, and lightning-caused fires are common in the forests adjacent to the canyon grasslands (Tisdale 1986). According to Agee (1996), Pseudoroegneria spicata communities in the Blue Mountains of northeastern Oregon and southeastern Washington produce enough fuel to burn annually.

Heavy grazing in the canyon grasslands was not only associated with decreased fire frequencies but also with the establishment and spread of several nonnative species. After 1870, European

${ }^{1}$ Department of Rangeland Ecology and Management, University of Idaho, Moscow, ID 83844.

${ }^{2}$ Present address: USDA Forest Service, Rocky Mountain Research Station, Fire Sciences Laboratory, 5575 Highway 10 West, Missoula, MT 59808. E-mail: cgucker@fs.fed.us 
settlement and livestock production in the canyon grasslands was extensive (Evans 1967, Tisdale 1986). High stocking rates, high growing-season utilization, and large concentrations of animals on the gentle slopes reduced the abundance of native bunchgrass and forb species and increased the abundance of nonnative species (Tisdale 1986). Some suggest that P. spicata grasslands did not evolve with intense grazing by large herbivores and that livestock introductions compromised grassland resilience (Mack and Thompson 1982). In southeastern Washington, growingseason clipping treatments led to the near replacement of $P$. spicata by native and nonnative annual species (Daubenmire 1940).

Bromus tectorum and Centaurea solstitialis are nonnative species that have been associated with "overgrazing” (Daubenmire 1970, Franklin and Dyrness 1973, Maddox and Mayfield 1985, DiTomaso 2000) and are common and widespread in the canyon grasslands. These species are well known as aggressive and troublesome rangeland species. Once grasslands are replaced by $B$. tectorum and $C$. solstitialis, their forage value is reduced, and ecosystem processes and watershed functions can be altered (Sheley and Larson 1994). Bromus tectorum is a persistent winter annual that can replace native plants in heavily invaded areas, increase fire frequencies (Whisenant 1990, Peters and Bunting 1994, Knapp 1996, Vitousek et al. 1996, Brooks and Pyke 2001), and disrupt litter, soil-moisture, and nutrient-cycling dynamics (Aguirre and Johnson 1991, Rosentreter 1994). Centaurea solstitialis, also a winter annual, can displace native vegetation, discourage wildlife and livestock use, and reduce recreation opportunities in invaded areas (Roche and Roche 1988, DiTomaso 2001). In annual grasslands and woodlands in California, large C. solstitialis populations have been associated with low soil-moisture levels early in the growing season and disruptions in water cycling (Benefield et al. 1998, DiTomaso 2001).

Conditions that increase the success of invasive species in stable native plant communities may occur on burned sites where canopies are removed and nutrients released (Vogl 1974, Hobbs and Huenneke 1992, With 2002), suggesting that the Maloney Creek fire may have facilitated increases in B. tectorum and C. solstitialis abundance.

In order to protect intact native plant communities from potential increases in nonnative species abundance, understanding their response to fire is critical. With this information, land managers could predict community changes, prepare for negative effects, and possibly leverage positive effects. Previous research in the study area suggests that communities with greater than 10\%-15\% native bunchgrass cover may resist $C$. solstitialis invasion (Robins 2001). Young and Evans (1978) also reported that a threshold density of perennial grasses in Artemisia tridentata habitats restricted establishment of B. tectorum and other nonnative annuals.

This study was initiated to provide information to land managers about the effects of a late-summer fire on native and nonnative canyon grassland vegetation. In the majority of fire-effects studies, reference sites are established in sites near the burned area that are deemed similar to the burned community. This study allowed us the unique opportunity to compare species composition and abundance on the same plots before and after fire. Because grazing had not occurred in the study area for nearly 10 years, pre- and postfire effects are not confounded by multiple, simultaneous, large-scale disturbances.

Objectives of this study were to (1) document the changes in nonnative and native species canopy cover following fire, (2) determine if fire facilitated increases in C. solstitialis and other nonnative species, and (3) evaluate changes in dominant species cover with respect to prefire seral stage. It is important to note that because this study involves a single watershed and compares effects of a single fire, the independence assumption of ANOVA was violated. However, given the unique aspects of the study discussed above and the general difficulty in meeting ANOVA assumptions in ecological field studies, we still consider findings of this study valuable.

\section{Methods \\ Study Area}

The Craig Mountain Wildlife Management Area is located roughly $40 \mathrm{~km}$ south of Lewiston, Idaho, in Nez Perce and Lewis counties. Study sites were located within the Garden Creek Nature Preserve (GCNP) that occupies approximately 4761 ha of Craig Mountain. The GCNP is jointly managed by The Nature Conservancy and the Bureau of Land Management. In this area, annual precipitation averages $30 \mathrm{~cm}$ and most comes as winter snow and spring rain. In the hottest and coldest months, temperatures 
average $31.7^{\circ} \mathrm{C}$ and $3.9^{\circ} \mathrm{C}$, respectively (Western Regional Climate Center 2004).

The Maloney Creek fire burned from 15 to 24 August 2000 and covered an area of approximately 30,155 ha, which included part of the GCNP (Inside Idaho 2000, USDA Forest Service 2000). A backing fire, set during suppression efforts on 21 August 2000, burned study plots in the China Creek watershed. Study plots in the adjacent Corral Creek watershed did not burn. The backing fire was set at the southernmost point of the fire line and burned with low severity (Thom Hawkins, Craig Mountain Area Supervisor, Idaho Department of Lands, personal communication, 2004). At the time of the backing fire, humidity was $27 \%-33 \%$, air temperature averaged $23.6^{\circ} \mathrm{C}$, and winds were $0-16.7 \mathrm{~km}$. hour $^{-1}$ with gusts up to $35.2 \mathrm{~km} \cdot$ hour $^{-1}$ (Weather Underground 2004).

The Maloney Creek fire followed 45 days of below-average precipitation, but immediately following the fire, precipitation levels were much above the long-term average. Growingseason precipitation was near average in the first postfire year (2001), below average in the second postfire year (2002), and above average in the third postfire year (2003).

Attributes of the vegetation within the P. spicata-Poa secunda-Balsamorhiza sagittata habitat type were evaluated in late May or early June from 1999 to 2003. Sampled plots occurred on south to southwest slopes of $16 \%-52 \%$, at elevations of 796-1046 m, on predominantly stony silt loam soils (Tisdale 1986). Prefire data were collected in 1999 and 2000 (Robins 2001); postfire data were collected in 2002 and 2003, 2 and 3 years following the fire.

\section{Vegetation Sampling}

In this study, we referred to the most highly disturbed communities with the largest nonnative species component as early seral, the least-disturbed communities with the largest native species component as late seral, and communities between these extremes as mid-seral. Early-seral communities typically occurred on gentle slopes, where historic livestock concentrations and grazing were likely greatest. Lateseral communities often occupied the steepest and uppermost slopes that were likely avoided by livestock. Although we have used successional terms to describe these communities, we acknowledge that the most highly disturbed and altered early-seral communities may have crossed a threshold and may no longer represent the early successional stage of the P. spicata-Poa secunda-Balsamorhiza sagittata habitat type. For all species, the effects of the fire (burned vs. unburned treatment) were assessed using all early-, mid-, and late-seral plots. For the dominant native and nonnative species, we also assessed differences between burned and unburned plots separately by seral stage. However, small sample sizes restrict us to presenting only observed trends with respect to different seral communities.

Within the P. spicata-Poa secunda-Balsamorhiza sagittata habitat type, there were 25 macroplots that measured $25 \times 25 \mathrm{~m}$. Six macroplots were classified as early-seral, 11 as mid-seral, and 8 as late-seral communities. Seral stage was assessed and assigned prior to prefire vegetation sampling. Two of the early-seral, 6 of the midseral, and 3 of the late-seral plots burned in 2000.

Canopy cover of species within the macroplots was estimated visually for $20 \times 50$-cm quadrats using the cover-class method established by Daubenmire (1959) and revised by Bailey and Poulton (1968). Canopy cover was evaluated at each meter along 5 randomly placed 10 -m transects for a total of 50 quadrats per macroplot.

\section{Data Analysis}

Cover data were analyzed for 9 dominant forb and grass species and for less-abundant forbs that were analyzed as groups of perennial forbs, leguminous forbs, nonnative annual forbs, and native annual forbs. Cover differences for species and groups were evaluated over time on burned and unburned plots using a linear mixed-effects model (Littell et al. 1996). Because we analyzed effects of a single fire, the independence assumptions for the ANOVA were violated. Cover was log transformed to meet normalcy requirements of the model. Covariance structure was individually assigned based on the lowest Akaike's information criterion (AIC) obtained. For those species and species groups that showed a significant change with respect to treatment (burned vs. unburned) over time, we assessed the significance of cover differences in each year.

Diversity indices (richness, Pielou's evenness, Simpson, and Shannon-Weiner) were calculated for all years on burned and unburned plots (McCune and Grace 2002). Community changes within early-, mid-, and late-seral plots were also 
TABLE 1. Average pre- and postfire percent cover on burned and unburned plots for those species and species groups for which time $\times$ treatment interactions were significant $(P<0.05)$. $\mathrm{N}=$ native, $\mathrm{I}=$ introduced, $\mathrm{P}=$ perennial, $\mathrm{A}=$ annual, $\mathrm{UB}=$ unburned, and $\mathrm{B}=$ burned as of 2002 sampling. Burned and unburned coverage values with different letters for a species or species group within the same year are significantly different $(P<0.05)$. Statistical differences are based on log-transformed cover data, although absolute cover data is presented in the table.

\begin{tabular}{|c|c|c|c|c|c|c|}
\hline & & & 1999 & 2000 & 2002 & 2003 \\
\hline Time since fire (years) & & & prefire & prefire & 2 & 3 \\
\hline \multicolumn{7}{|l|}{ Grasses } \\
\hline \multirow[t]{2}{*}{ Pseudoroegneria spicata } & NP & UB & $20.10 \mathrm{a}$ & $16.38 \mathrm{a}$ & $25.28 \mathrm{~b}$ & $26.34 \mathrm{a}$ \\
\hline & & B & $17.74 \mathrm{a}$ & $18.66 \mathrm{a}$ & $15.56 \mathrm{a}$ & $21.53 \mathrm{a}$ \\
\hline \multirow[t]{2}{*}{ Bromus tectorum } & IA & UB & $1.36 \mathrm{a}$ & $1.46 \mathrm{~b}$ & $5.96 \mathrm{~b}$ & $6.26 \mathrm{a}$ \\
\hline & & B & $0.76 \mathrm{a}$ & $0.22 \mathrm{a}$ & $1.74 \mathrm{a}$ & $7.73 \mathrm{a}$ \\
\hline \multirow[t]{2}{*}{ Bromus arvensis } & IA & UB & $6.99 \mathrm{a}$ & $6.93 \mathrm{a}$ & $13.02 \mathrm{~b}$ & $10.25 \mathrm{a}$ \\
\hline & & B & $9.95 \mathrm{a}$ & $5.22 \mathrm{a}$ & $6.75 \mathrm{a}$ & $8.90 \mathrm{a}$ \\
\hline \multirow{2}{*}{ Poa secunda } & NP & UB & $0.27 \mathrm{a}$ & $0.29 \mathrm{a}$ & $0.39 \mathrm{a}$ & $0.28 \mathrm{a}$ \\
\hline & & B & $0.17 \mathrm{a}$ & $0.15 \mathrm{a}$ & $1.67 \mathrm{~b}$ & $3.28 \mathrm{~b}$ \\
\hline \multicolumn{7}{|l|}{ Forbs } \\
\hline \multirow[t]{2}{*}{ Balsamorhiza sagittata } & NP & UB & $8.57 \mathrm{a}$ & $6.81 \mathrm{a}$ & $6.85 \mathrm{a}$ & $6.54 \mathrm{a}$ \\
\hline & & B & $9.57 \mathrm{a}$ & $12.95 \mathrm{a}$ & $6.82 \mathrm{a}$ & $7.40 \mathrm{a}$ \\
\hline \multirow[t]{2}{*}{ Achillea millefolium } & NP & UB & $2.26 \mathrm{a}$ & $1.35 \mathrm{a}$ & $1.77 \mathrm{a}$ & $1.19 \mathrm{a}$ \\
\hline & & B & $4.03 \mathrm{~b}$ & $2.81 \mathrm{~b}$ & $1.32 \mathrm{a}$ & $0.78 \mathrm{a}$ \\
\hline \multirow[t]{2}{*}{ Lupinus sericeus } & NP & UB & $2.34 \mathrm{a}$ & $2.39 \mathrm{a}$ & $2.26 \mathrm{a}$ & $1.31 \mathrm{a}$ \\
\hline & & B & $3.89 \mathrm{a}$ & $4.45 \mathrm{a}$ & $3.37 \mathrm{a}$ & $6.93 \mathrm{~b}$ \\
\hline \multirow[t]{2}{*}{ Phlox colubrina } & NP & UB & $0.20 \mathrm{a}$ & $0.27 \mathrm{a}$ & $0.71 \mathrm{a}$ & $0.39 \mathrm{a}$ \\
\hline & & B & $0.24 \mathrm{a}$ & $0.17 \mathrm{a}$ & $0.41 \mathrm{a}$ & $0.09 \mathrm{~b}$ \\
\hline \multirow[t]{2}{*}{ Centaurea solstitialis } & IA & UB & $13.91 \mathrm{a}$ & $7.11 \mathrm{a}$ & $9.52 \mathrm{a}$ & $4.43 \mathrm{a}$ \\
\hline & & B & $7.13 \mathrm{a}$ & $7.08 \mathrm{a}$ & $6.32 \mathrm{a}$ & $6.62 \mathrm{a}$ \\
\hline \multirow[t]{2}{*}{ Other leguminous forbs } & & UB & $1.38 \mathrm{a}$ & $1.44 \mathrm{a}$ & $1.65 \mathrm{a}$ & $1.48 \mathrm{a}$ \\
\hline & & B & $1.49 \mathrm{a}$ & $0.99 \mathrm{a}$ & $1.82 \mathrm{a}$ & $2.34 \mathrm{a}$ \\
\hline \multirow[t]{2}{*}{ Other nonnative annual forbs } & & UB & $0.81 \mathrm{a}$ & $1.07 \mathrm{~b}$ & $3.78 \mathrm{a}$ & $3.56 \mathrm{a}$ \\
\hline & & B & $0.75 \mathrm{a}$ & $0.43 \mathrm{a}$ & $6.22 \mathrm{a}$ & $7.85 \mathrm{~b}$ \\
\hline \multirow[t]{2}{*}{ Other native annual forbs } & & UB & $0.25 \mathrm{a}$ & $0.31 \mathrm{a}$ & $0.67 \mathrm{a}$ & $1.86 \mathrm{a}$ \\
\hline & & $\mathrm{B}$ & $0.18 \mathrm{a}$ & $0.16 \mathrm{a}$ & $1.68 \mathrm{a}$ & $4.22 \mathrm{~b}$ \\
\hline \multirow[t]{2}{*}{ Other perennial forbs } & & UB & $1.36 \mathrm{a}$ & $2.55 \mathrm{a}$ & $5.36 \mathrm{a}$ & $7.22 \mathrm{a}$ \\
\hline & & B & $1.41 \mathrm{a}$ & $1.25 \mathrm{a}$ & $3.25 \mathrm{a}$ & $5.89 \mathrm{a}$ \\
\hline
\end{tabular}

analyzed for P. spicata, Poa secunda, B. tectorum, and C. solstitialis using linear mixed-effects modeling. Overall $P$ values reported in the results section reflect interactions between time (year), treatment (burned vs. unburned), and block (seral stage). For dominant native and nonnative species with significant overall $P$ values, the significance of treatment differences was calculated for each year within a seral stage.

\section{Results}

\section{Native and Nonnative Species}

In the GCNP canyon grasslands, species composition and species dominance was not substantially changed by the summer wildfire regardless of the prefire seral community (Table 1).

Pseudoroegneria spicata cover decreased briefly following fire. In the second postfire year, cover was significantly lower on burned than unburned plots $(P=0.035)$, but by the third postfire year, cover was not significantly different on burned and unburned plots and was greater than prefire levels on burned plots. Poa secunda cover was significantly greater on burned than unburned plots in the second $(P=0.045)$ and third postfire years $(P<0.0001)$.

Bromus tectorum cover increased substantially following fire. Before the fire, cover of $B$. tectorum was significantly greater on unburned than burned plots $(P=0.002)$, but by the third postfire year, cover was similar on burned and unburned plots. Cover of Bromus arvensis increased on both burned and unburned plots following the fire, but in the second postfire year, cover was significantly greater on unburned than burned plots $(P=0.017)$, and in the third postfire year these differences were lost.

There were no significant differences in $\mathrm{Bal}$ samorhiza sagittata cover on burned and unburned plots in any year, although cover was nearly $13 \%$ just before the fire and $6.8 \%$ two years after fire. In the third postfire year, Phlox 
colubrina cover was significantly lower on burned than unburned plots $(P=0.02)$. Cover of Lupinus sericeus decreased on unburned plots and increased on burned plots over the course of the study. By the third postfire year, L. sericeus cover was significantly greater on burned plots than on unburned plots $(P<0.0001)$. Before the fire, Achillea millefolium cover was significantly greater on burned than unburned plots $(P \leq$ 0.014 ), but after the fire, cover was significantly lower on burned plots than on unburned plots $(P<0.05)$. Centaurea solstitialis cover was unchanged by the fire.

Nonnative annual forbs other than C. solstitialis were analyzed as a group. Nonnative annual forbs increased on burned plots $(P<0.001)$. Before the fire, cover of nonnative annuals was significantly greater on unburned than burned plots $(P=0.018)$, but by the third postfire year, cover was significantly $(P=0.003)$ greater on burned than unburned plots. For the other species groups-perennial forbs, leguminous forbs, and native annual forbs-time $\times$ treatment interactions were not significant.

\section{Diversity}

All diversity indices produced significant $(P$ $<0.05)$ time $\times$ treatment interactions. Evenness was not different on burned and unburned plots before the fire, but in the third postfire year, evenness was significantly greater on burned than unburned plots $(P=0.001)$, suggesting a homogenization of species cover on burned plots. Diversity (both Simpson's and Shannon-Weiner indices) was significantly greater on burned than unburned plots in the second and third postfire years $(P<0.03)$. However, species richness on burned and unburned plots was not significantly different in any year, and typically, species that were dominant within a plot before the fire were dominant after the fire.

\section{Seral Stage}

The overall time $\times$ treatment $\times$ seral stage interactions were significant $(P<0.05)$ for earlyseral (C. solstitialis and B. tectorum) and late-seral (P. spicata and Poa secunda) dominants. Sample sizes within a given seral stage were small, so findings discussed here can only be interpreted as trends. Cover of $P$. spicata decreased on lateseral burned plots and increased on early-seral burned plots. Cover increases from prefire levels were greatest for early-seral plots (Fig. 1A). By the third postfire year, Poa secunda cover was significantly $(P<0.02)$ greater on burned than unburned plots regardless of seral stage (Fig. 1B).

After the fire, C. solstitialis cover changes on burned and unburned plots were similar for each seral stage (Fig. 1C). On burned and unburned early-seral plots, cover decreased substantially. In mid-seral plots, $C$. solstitialis cover was significantly $(P=0.034)$ greater on unburned than burned plots in the season before the fire, but these differences were lost after the fire. Bromus tectorum cover increased over time on burned and unburned plots of all seral stages (Fig. 1D). In late-seral plots, however, B. tectorum cover was significantly greater on unburned than burned plots before the fire and in the second postfire year $(P<0.01)$, but by the third postfire year, cover was not significantly different on burned and unburned late-seral plots.

\section{DisCUSSION}

Although there were species-specific changes following the fire, the species that dominated before the fire generally dominated after the fire. Bromus tectorum increased following fire, as expected, but the fire did not produce large increases in C. solstitialis. Large changes in successional trajectories were not apparent following the fire. Small changes included increased cover of P. spicata and Poa secunda and decreased cover of $C$. solstitialis on early-seral burned plots, as well as decreased cover of P. spicata and increased cover of B. tectorum on late-seral burned plots. Due to our small sample sizes, however, we cannot say with any certainty that burning advanced early-seral plots and set back late-seral plots.

The primary period of vegetation growth in the P. spicata-Poa secunda-Balsamorhiza sagittata habitat type occurs from April to June (Tisdale 1986), well before the Maloney Creek fire. Because it was a low-severity fire that burned when most vegetation was summer dormant, little change in species composition should be expected. Grassland fires often spread quickly because of rapid fuel consumption and may not produce lethal temperatures (Daubenmire 1968), making species turnover unlikely. Small overall changes in species composition and abundance may also indicate that the early-, mid-, and lateseral communities are relatively stable and largely unaffected by dormant-season burning. Gray and Lichthardt (2003) also reported relatively unchanged species composition during their 

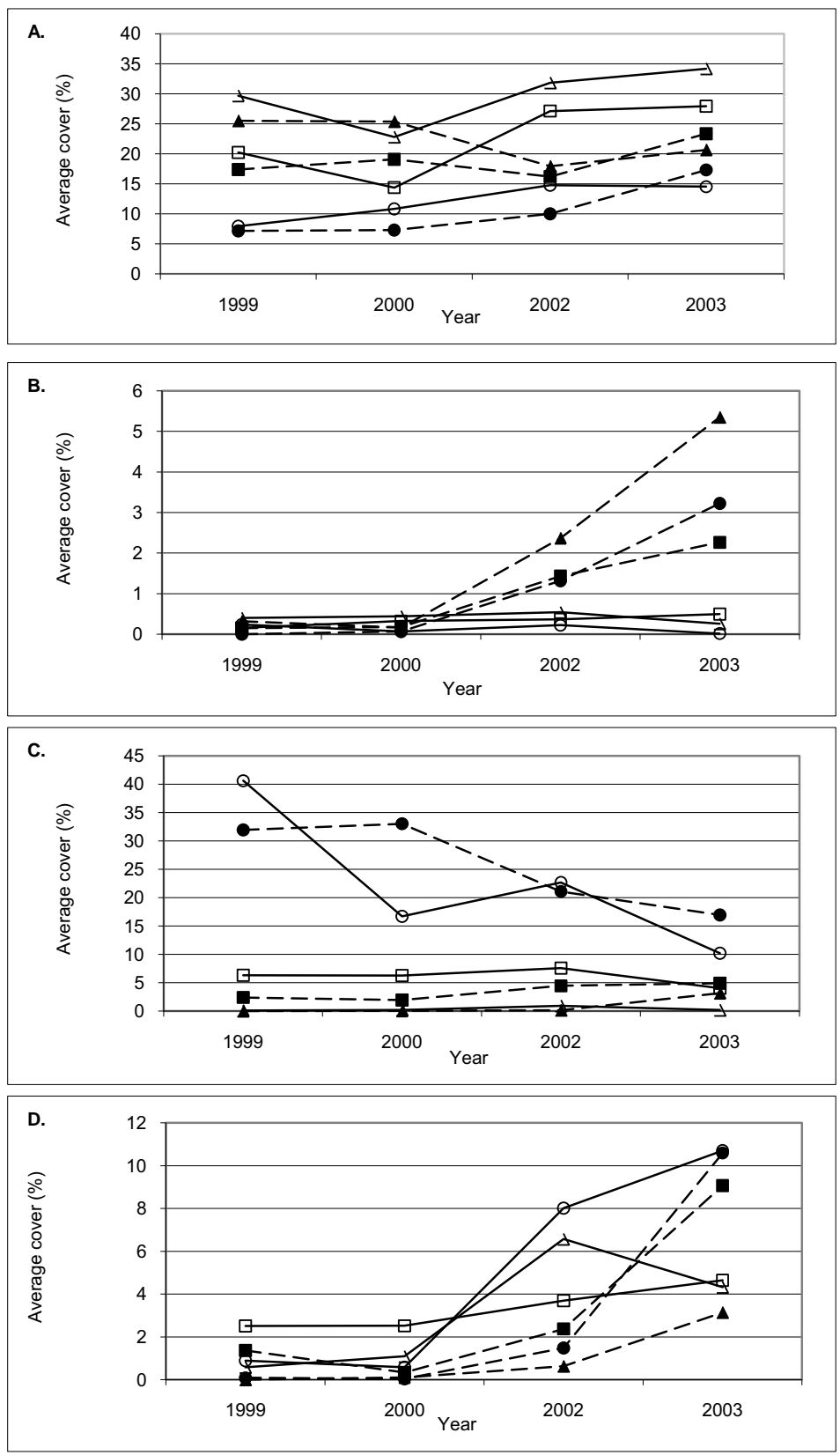

Fig. 1. Average cover of Pseudoroegneria spicata (A), Poa secunda (B), Centaurea solstitialis (C), and Bromus tectorum (D) on early-seral (circles), mid-seral (squares), and late-seral (triangles) burned (dashed line) and unburned (solid line) plots. Data for 1999 and 2000 were collected before the fire. Absolute cover values are presented, but statistical significance was evaluated from log-transformed data.

7-year postfire study of Craig Mountain canyon grasslands.

In this study, above-average postfire precipitation likely improved vegetation recovery. Others have suggested that the postfire abundance of B. tectorum and C. solstitialis can be affected by precipitation (West and Hassan 1985, Hosten and West 1994, West and Yorks 2002, DiTomaso et al. 2006). In Artemisia tridentata habitats in central Utah, B. tectorum was less abundant in 
dry postfire conditions than in wet postfire conditions (West and Hassan 1985, Hosten and West 1994, West and Yorks 2002). Centaurea solstitialis seedlings that germinated after late-winter or early-spring fires in Siskiyou County, California, died when postfire drought conditions were severe (DiTomaso et al. 2006). Removal of the litter layer on burned sites often restricts the establishment of $B$. arvensis, but with aboveaverage postfire precipitation, establishment occurs (Whisenant and Uresk 1990).

In our study, native bunchgrass cover exceeded prefire cover by the third postfire year. Other researchers have also reported that Pseudoroegneria spicata can recover to prefire or unburned abundance within 3 years of dormantseason burning (Strang 1989, Bunting et al. 1998). Increased abundance of Poa secunda following rangeland fires has been reported by many (Daubenmire 1975, Antos et al. 1983, Bork et al. 2002). Other research from our study area reported a greater frequency of $P$. secunda on burned than unburned plots and nearly equal frequency of Pseudoroegneria spicata on burned and unburned plots (Gray and Lichthardt 2003). Gray and Lichthardt (2003) reported changes in species frequency following fire, whereas we reported changes in species cover; therefore, the magnitudes of abundance changes will likely be different between the studies.

Research suggests that fire could increase native plant size and/or recruitment and potentially decrease a community's susceptibility to invasion by nonnative species (Young and Evans 1978, Robins 2001). From a management perspective, fire may be most effective in maintaining cover of dominant native species in areas without a substantial nonnative species component. On sites dominated by nonnative species, burning is unlikely to produce substantial increases in native species abundance without seeding or planting native species (Klinger et al. 2006). In our study area, large areas are dominated by $C$. solstitialis and B. tectorum. It is possible that the native plant communities in these areas have been irreversibly transformed by these nonnative species. Control of the nonnative species will be difficult and likely require integrated- and adaptive-management techniques (Klinger et al. 2006).

Rangelands like the canyon grasslands that support both C. solstitialis and B. tectorum are common, and several studies have documented that changes in abundance of one species may affect the growth and abundance of the other (Larson and Sheley 1994, Sheley and Larson 1997, DiTomaso et al. 2000). Gray and Lichthardt (2003) observed that B. tectorum-dominated sites became dominated by $C$. solstitialis over time and suggested that the presence of $B$. tectorum may have facilitated invasion by $C$. solstitialis. Rangeland management with both C. solstitialis and B. tectorum should anticipate that management treatments or unplanned disturbances may affect these species differently, and long-term control plans for one species should address potential increases in the other.

\section{Implications}

Based on our findings, low-severity, dormantseason fires are not likely to produce large changes in canyon grassland species composition and abundance. Given the large demands placed on the budgets, time, and limited staff of today's land managers, prioritization of projects and treatments is paramount. Our study suggests that postfire rehabilitation following low-severity, late-summer wildfires in $P$. spicata grasslands may be a low priority for land managers.

\section{ACKNOWLEDGMENTS}

We thank Dr. Jim Kingery and Dr. Tim Prather for their help and comments that aided the direction and completion of this study. Many thanks go to Sandra Robins who collected all the prefire data used in this study. We thank Art Talsma and The Nature Conservancy for providing accommodations throughout the summer field seasons. We thank Lynn Danly and the Bureau of Land Management for helping us access and understand the management history of the study area. We are grateful for the statistical advice provided by Dr. Chris Williams. Finally, we thank students and staff of the Rangeland Ecology and Management Department at the University of Idaho, as well as staff at the Forest Service's Rocky Mountain Research Station in Missoula, Montana, for their support of this project.

This publication is issued as Contribution No. 1053 of the Idaho Forest, Wildlife and Range Experiment Station, University of Idaho, Moscow.

\section{Literature Cited}

AgEe, J.K. 1996. Fire in the Blue Mountains: a history, ecology, and research agenda. Pages 119-145 in R.G. Jaindl and T.M. Quigley, editors, Search for a solution: 
sustaining the land, people and economy of the Blue Mountains. American Forests, Washington, DC.

AguirRe, L., AND D.A. JoHnSON. 1991. Influence of temperature and cheatgrass competition on seedling development of two bunchgrasses. Journal of Range Management 44:347-354.

Antos, J.A., B. McCune, And C. Bara. 1983. The effect of fire on an ungrazed western Montana grassland. American Midland Naturalist 110:354-364.

ARNO, S.F. 1996. The concept: restoring ecological structure and process in ponderosa pine forests. Pages $37-38$ in C.C. Hardy and S.F. Arno, editors, The use of fire in forest restoration: a general session at the Annual Meeting of the Society for Ecological Restoration [4-16 September 1995]. INT-GTR-341, USDA Forest Service, Intermountain Research Station, Ogden, UT.

Bailey, A.W., AND C.E. Poulton. 1968. Plant communities and environmental interrelationships in a portion of the Tillamook Burn, northwestern Oregon. Ecology 49:1-13.

Benefield, C.B., J.M. DiTomaso, and G.B. KySER. 1998. Impacts of yellow starthistle density on the soil moisture profile and rangeland management. Proceedings, Western Society of Weed Science 51:66.

Bork, E.W., B.W. Adams, and W.D. Willms. 2002. Resilience of foothills rough fescue, Festuca campestris, rangeland to wildfire. Canadian Field-Naturalist 116: 51-59.

BRooks, M.L., AND D. PYKe. 2001. Invasive plants and fire in the deserts of North America. Pages 1-14 in K.E.M. Galley and T.P. Wilson, editors, Proceedings of the Invasive Species Workshop: the role of fire in the control and spread of invasive species. Miscellaneous Publication No. 11. Fire Conference 2000: 1st National Congress on Fire Ecology, Prevention, and Management, San Diego, CA.

Bunting, S.C., R. Robberecht, and G.E. Defosse. 1998. Length and timing of grazing on postburn productivity of two bunchgrasses in an Idaho experimental range. International Journal of Wildland Fire 8:15-20.

Christensen, N.L., A.M. Bartuska, J.H. Brown, S. Carpenter, C. D'Antonio, R. Francis, J.F. Franklin, et al. 1996. The report of the Ecological Society of America Committee on the Scientific Basis for Ecosystem Management. Ecological Applications 6:665-691.

DAUbenmiRe, R. 1940. Plant succession due to overgrazing in the Agropyron bunchgrass prairie of southeastern Washington. Ecology 21:55-64.

1959. A canopy-coverage method of vegetational analysis. Northwest Science 33:43-64.

. 1968. Ecology of grasslands. Advances in Ecological Research 5:209-266.

1970. Steppe vegetation of Washington. Technical Bulletin 62, Washington State University [College of Agriculture] and Washington Agricultural Experiment Station, Pullman, WA. 131 pp.

1975. Plant succession on abandoned fields, and fire influences, in a steppe area in southeastern Washington. Northwest Science 49:36-48.

DiTomaso, J. 2001. Element stewardship abstract: Centaurea solstitialis $\mathrm{L}$. In: Weeds on the Web: The Nature Conservancy Wildland Invasive Species Program. [Cited 19 December 2001]. Available from: http://tncweeds ucdavis.edu/esadocs/documnts/centsols.html

DiTomaso, J.M. 2000. Invasive weeds in rangelands: species, impacts, and management. Weed Science 48:255-265.

DiTomaso, J.M., G.B. Kyser, J.R. Miller, G. Sergio, R.F. SMith, G. NADER, J.M. CONNOR, ET AL. 2006. Integrating prescribed burning and clopyralid for the management of yellow starthistle (Centaurea solstitialis). Weed Science 54:757-767.

DiTomaso, J.M., G.B. Kyser, S.B. Orloff, and S.F. Enloe. 2000. Integrated strategies offer site-specific control of yellow starthistle. California Agriculture 54(6):30-36.

EvANS, G.R. 1967. Ecology of Aristida longiseta in northcentral Idaho. Masters thesis, University of Idaho, Moscow, ID.

FrankLin, J.F., AND C.T. Dyrness. 1973. Natural vegetation of Oregon and Washington. General Technical Report PNW-8, USDA Forest Service, Pacific Northwest Forest and Range Experiment Station, Portland, OR.

GRAY, K., AND J. LiCHTHARDT. 2003. Long-term monitoring of canyon grasslands at Craig Mountain, Idaho: eighthyear data. Upper Columbia-Salmon Clearwater District Assistance Agreement DAA000203: task order DAF02 0071. Idaho Department of Fish and Game [producer], Boise, ID; [cited 22 April 2009]. Available from: http:// fishandgame.idaho.gov/cdc/cdc pdf/u03gra01.pdf

Greene, S.E., And A. Evenden. 1996. The role of fire in Research Natural Areas in the Northern Rockies and Pacific Northwest. Pages 32-33 in C.C. Hardy and S.F. Arno, editors, The use of fire in forest restoration: a general session at the Annual Meeting of the Society for Ecological Restoration [14-16 September 1995]. INTGTR-341, USDA Forest Service, Intermountain Research Station, Ogden, UT.

Hobbs, R.J., And L.F. Huenneke. 1992. Disturbance, diversity, and invasion: implications for conservation. Conservation Biology 6:324-337.

Hosten, P.E., AND N.E. West. 1994. Cheatgrass dynamics following wildfire on a sagebrush semidesert site in central Utah. Pages 56-62 in S.B. Monsen and S.G. Kitchen, compilers, Proceedings: ecology and management of annual rangelands [18-22 May 1992]. INTGTR-313, USDA Forest Service, Intermountain Research Station, Boise, ID.

INSIDE IDAHO. 2000. Interactive numeric and spatial information data engine. University of Idaho, Moscow, ID; [cited 20 October 2003]. Available from: http://inside .uidaho.edu

JoHnson, C.A. 1989. Early spring prescribed burning of big game winter range in the Snake River Canyon of westcentral Idaho. Pages 151-155 in D.M. Baumgartner, D.W. Breuer, B.A. Zamora, L.F. Neuenschwander, and R.H. Wakimoto, compilers, Prescribed fire in the Intermountain region: forest site preparation and range improvement symposium proceedings [3-5 March 1986]. Washington State University, Department of Natural Resources, Cooperative Extension, Spokane, WA.

Klinger, R.C., M.L. BRoOKs, AND J.M. Randall. 2006. Fire and invasive plant species. Pages 499-519 in N.G. Sugihara, J.W. van Wagendonk, K.E. Shaffer, J. FitesKaufman, and A.E. Thode, editors, Fire in California's ecosystems. University of California Press, Berkeley, CA.

KNAPP, P.A. 1996. Cheatgrass (Bromus tectorum L.) dominance in the Great Basin Desert: history, persistence, and influences to human activities. Global Environmental Change 6:37-52

LARSON, L.L., AND R.L. SHELEy. 1994. Ecological relationships between yellow starthistle and cheatgrass. Pages 92-94 in S.B. Monsen and S.G. Kitchen, compilers, Proceedings: ecology and management of annual rangelands [18-22 May 1992]. INT-GTR-313, USDA Forest Service, Intermountain Research Station, Ogden, UT. 
LEACH, M.K., AND T.J. GIVNISH. 1996. Ecological determinants of species loss in remnant prairies. Science 273 $1555-1558$.

Littell, R.C., G.A. Milliken, W.W. Stroup, and R.D. WOLFINGER. 1996. SAS system for mixed models. SAS Institute, Inc., Cary, NC.

MaCK, R.N., AND J.N. ThOmpson. 1982. Evolution in steppe with few large, hooved mammals. American Naturalist 119:757-773.

Maddox, D.A., AND A. MaYfiELd. 1985. Yellow starthistle infestations are on the rise. California Agriculture 39(6): 10-12.

McCune, B., And J.B. Grace. 2002. Analysis of ecological communities. MjM Software Design, Gleneden Beach, OR.

Peters, E.F., And S.C. Bunting. 1994. Fire conditions preand postoccurrence of annual grasses on the Snake River Plain. Pages 31-36 in S.B. Monsen and S.G. Kitchen, compilers, Proceedings: ecology and management of annual rangelands [18-22 May 1992]. INT-GTR-313, USDA Forest Service, Intermountain Research Station, Ogden, UT.

RoBins, S.S. 2001. Effects of perennial plant competition on the invasibility of canyon grassland communities by Centaurea solstitialis. Master's thesis, University of Idaho, Moscow, ID.

Roche, C.T., AND B.F. Roche. 1988. Distribution and amount of four knapweed (Centaurea L.) species found in eastern Washington. Northwest Science 62:242-253.

Rosentreter, R. 1994. Displacement of rare plants by exotic grasses. Pages 170-175 in S.B. Monsen and S.G. Kitchen, compilers, Proceedings: ecology and management of annual rangelands [18-22 May 1992]. INT-GTR313, USDA Forest Service, Intermountain Research Station, Ogden, UT.

Sheley, R.L., AND L.L. LARSON. 1994. Observation: comparative live-history of cheatgrass and yellow starthistle. Journal of Range Management 47:450-456.

1997. Cheatgrass and yellow starthistle growth at 3 soil depths. Journal of Range Management 50:146-150.

STRANG, R.M. 1989. Impacts of fire on herbaceous vegetation. Pages 111-112 in D.M. Baumgartner, D.W. Breuer, B.A. Zamora, L.F. Neuenschwander, and R.H. Wakimoto, compilers, Prescribed fire in the Intermountain region: forest site preparation and range improvement symposium proceedings [3-5 March 1986]. Washington State University, Department of Natural Resources, Cooperative Extension, Spokane, WA.

Tisdale, E.W. 1979. A preliminary classification of Snake River canyon grasslands in Idaho. Station Note No. 32,
Forest, Wildlife, and Range Experiment Station, University of Idaho, Moscow, ID.

1986. Canyon grasslands and associated shrublands of west-central Idaho and adjacent areas. Bulletin Number 40, Forest, Wildlife and Range Experiment Station, College of Forestry, Wildlife and Range Sciences, University of Idaho, Moscow, ID.

USDA ForEST SERVICE. 2000 McCall, ID; [cited 15 November 2002]. Available from: http://www.fs.fed.us/rl/ecol ogy fire2000/.

Vitousek, P.M., C.M. Dantonio, L.L. Loope, and R. WestBROOKS. 1996. Biological invasions as global environmental change. American Scientist 84:468-478.

VOGL, R.J. 1974. Effects of fire on grasslands. Pages 139-194 in T.T. Koslowski and C.E. Ahlgren, editors, Fire and ecosystems. Academic Press, San Fransisco, CA.

WeATHER Underground, InC. 2004. Weather data. [Cited 13 April 2004]. Available from: http://www.wunder ground.com/history/airport/KLSW/2000/8/20/Daily History.html

West, N.E., AND M.A. Hassan. 1985. Recovery of sagebrush-grass vegetation following wildfire. Journal of Range Management 38:131-134.

WEST, N.E., AND T.P. YoRKs. 2002. Vegetation responses following wildfire on grazed and ungrazed sagebrush semidesert. Journal of Range Management 55:171-181.

Western Regional Climate Center. 2004. Climate data. Division of Atmospheric Sciences, Desert Research Institute, NV; [cited 8 March 2004]. Available from: http://www.wrcc.dri.edu/index.html

WhisEnANT, S.G. 1990. Changing fire frequencies on Idaho's Snake River Plains: ecological and management implications. Pages 4-10 in E.D. McArthur, E.M. Romney, S.D. Smith, and P.T. Tueller, compilers, Proceedings: symposium on cheatgrass invasion, shrub die-off, and other aspects of shrub biology and management [5-7 April 1989]. General Technical Report INT-276, USDA Forest Service, Intermountain Research Station Las Vegas, NV.

Whisenant, S.G., AND D.W. UREsk. 1990. Spring burning Japanese brome in a western wheatgrass community. Journal of Range Management 43:205-208.

WiTH, K.A. 2002. The landscape ecology of invasive spread. Conservation Biology 16:1192-1203.

Young, J.A., AND R.A. Evans. 1978. Population dynamics after wildfires in sagebrush grasslands. Journal of Range Management 31:283-289.

Received 4 December 2009 Accepted 15 November 2010 